\title{
Friends' Influence on Academic Performance Among Early Adolescents: The Role of Social Status
}

\section{Influencia de los Amigos en el Rendimiento Académico entre Adolescentes Tempranos: El Rol del Estatus Social}

\author{
Diego Palacios ${ }^{1}$ and Christian Berger ${ }^{2}$ \\ ${ }^{1}$ Society and Health Research Center, Facultad de Ciencias Sociales y Artes, \\ Universidad Mayor, Chile \\ ${ }^{2}$ Escuela de Psicología, Pontificia Universidad Católica de Chile
}

\begin{abstract}
Educational research has shown that academic achievement and peer relationships are associated from early school years, where friends play a significant role in influencing students' school adjustment, attitudes, and behaviors. The present study examines how individual academic performance is associated with friendships among 240 5th and 6th graders. The information on students' friendships, academic performance, gender, popularity, and social preference was collected in a convenience sample from 8 classrooms of 2 private-subsidized schools in Santiago, Chile. Longitudinal social network analysis (RSiena) was used to study the co-evolution of academic performance and friendship dynamics, by assessing simultaneously selection and influence processes, and by incorporating social status covariates (popularity and social preference) as moderators of friendship selection and influence. Results showed that friendships were more likely to occur between same-sex peers and between students with similar social status. Regarding social influence, friends influenced individual's academic performance. Moreover, socially preferred students were more likely to be influenced by friends' academic performance, but the same did not occur for popular students. These results might suggest that socially preferred students' attributes (cooperation, reciprocity, and highquality friendships) would facilitate the influence of academic performance. In contrast, popular students would be less sensitive to their friends' academic performance focusing instead on salient behaviors (e.g., aggression). The findings underline the importance of understanding social network dynamics in educational settings.
\end{abstract}

Keywords: influence, social status, academic performance, social networks analysis, RSiena

La investigación educativa ha mostrado que los logros académicos y las relaciones con pares se asocian desde los primeros años escolares, donde las amistades juegan un papel importante al influir en el rendimiento escolar, así como en las actitudes y los comportamientos de los estudiantes. El presente estudio examina cómo el desempeño académico individual se asocia con las amistades en 240 estudiantes de quinto y sexto grado. La información sobre amistades, rendimiento académico, género, popularidad y preferencia social de los estudiantes se recopiló en una muestra de conveniencia de 8 aulas de 2 escuelas privadas subvencionadas en Santiago, Chile. Se utilizó el análisis longitudinal de redes sociales (RSiena) para estudiar la coevolución del rendimiento académico y la dinámica de la amistad mediante la evaluación simultánea de procesos de selección e influencia e incorporando covariables de estatus social (popularidad y preferencia social) como moderadores de la selección e influencia de las amistades. Los resultados mostraron que las amistades fueron más probables entre pares del mismo sexo y entre estudiantes con un estatus social similar. Con respecto a la influencia social, las amistades influyen en el rendimiento académico individual. Además, estudiantes socialmente preferidos tuvieron más probabilidades de verse influenciados por el rendimiento académico de sus amigas/os, pero no ocurrió lo mismo con los estudiantes populares. Estos resultados podrían sugerir que atributos asociados a estudiantes socialmente preferidos (cooperación, reciprocidad y amistades de alta calidad) facilitarían la influencia del rendimiento académico. Por el contrario, los estudiantes populares serían menos susceptibles al rendimiento académico de sus amigos, centrándose en cambio en comportamientos salientes (p. ej. agresión). Los hallazgos de esta investigación resaltan la importancia de comprender la dinámica de las redes sociales entre estudiantes en entornos educativos.

Palabras clave: influencia, estatus social, rendimiento académico, análisis de redes sociales, RSiena

Diego Palacios iD https://orcid.org/0000-0001-6840-0068
Christian Berger (iD https://orcid.org/0000-0003-1909-7490

The authors declare that they have no conflict of interest. This work was supported by the Comisión Nacional de Investigación Científica y Tecnológica (CONICYT PFCHA/DOCTORADO BECAS CHILE/2016 [7217010]) and the Fondo Nacional de Desarrollo Científico y Tecnológico (FONDECYT 1191692 and 11110037). Correspondence concerning this article should be addressed to Diego Palacios, Society and Health Research Center, Facultad de Ciencias Sociales y Artes, Universidad Mayor, Badajoz 130, room 1305, Las Condes, Santiago, Chile. E-mail: diego.palacios@umayor.cl 
PALACIOS AND BERGER

Academic adjustment constitutes one of the main challenges for children and adolescents worldwide. Therefore, studies from different perspectives have identified that familial, school, and personal characteristics (Kindermann, 2007; Marjoribanks, 1998) help to explain individual and contextual differences in academic outcomes (Eccles, 2004). This study adds to this literature by focusing on peer interactions, studying the co-evolution of individual academic performance and friendship dynamics among fifth and sixth graders. Specifically, this paper incorporates social status covariates (popularity and social preference) as moderators of the social influence process.

Peer influence becomes especially salient during the transition from childhood to adolescence (Buchmann \& Dalton, 2002; Bukowski \& Sippola, 2005), taking place in a broader social environment, such as classrooms and schools (Gest \& Rodkin, 2011; Lomi et al., 2011; Winston \& Zimmerman, 2003) in which specific behaviors are fostered or constrained by factors such as individual social status (e.g., popularity, social preference, admiration), the position of each student in the classroom network structure (e.g., centrality, closeness) and group norms. Nevertheless, even though earlier studies have consistently shown that befriended students display similar academic achievement and motivation (Kindermann, 2007; Ryan, 2001), peer influence on academic performance might not be straightforward (Johnson, 2000).

Methodological limitations have hindered the possibility of disentangling the causes of this similarity (Veenstra et al., 2013). These limitations refer to the consideration of only portions of students' interpersonal relationships but not the whole network, assuming the stability of peer groups and friendships and examining the selection and influence processes separately without an integrative approach to peer relations (Shin \& Ryan, 2014). Current research on peer relations has started to overcome these limitations by applying developmentally appropriate methods (Snijders et al., 2010). Specifically, stochastic actor-based models of social network analysis allow to test simultaneously changing individuals within changing networks, to understand how social networks unfold (selection processes), but also how individuals change within these relations (influence processes).

\section{Friendship Selection and Social Influence in School}

Within their peer ecology, students continuously make choices regarding their behaviors and with whom they are close or distant (Rodkin \& Ryan, 2012). As a result, early adolescents usually tend to display similar characteristics and attributes as their friends and peers who belong to the same groups. This similarity facilitates social coordination and, thus, integration and acceptance (Farmer et al., 2007). Studies have reported similarities for different behaviors, such as aggression (Berger \& Rodkin, 2012; Espelage et al., 2003), antisocial behavior (Piehler \& Dishion, 2007), prosocial behavior (Chen et al., 2010; Ellis \& Zarbatany, 2007), weapon carrying (Dijkstra, Lindenberg, et al., 2010), and academic motivation (Kindermann, 2007; Ryan, 2001) and achievement (Flashman, 2012). However, this similarity can be attributed to a selection process in which individuals choose each other based on shared characteristics (Haselager et al., 1998; Poulin \& Boivin, 2000) or to social influence, through learning from others or by reinforcement (Dishion \& Dodge, 2005).

On the one hand, children tend to sort themselves into friendships, selecting peers who are more or less similar to themselves. Different studies show that children tend to associate with other students with similar academic motivation (Kindermann, 1993; Kindermann et al., 1996) and academic performance (Wentzel \& Caldwell, 1997). On the other hand, peer relationships, such as friendships, also can modify individual behaviors and attitudes. Social influence would begin in middle childhood, where most of the children's peer interactions take place in groups (Rubin et al., 1998), which are often formed spontaneously out of common interests as networks of interacting individuals who spend time together and share activities. Thus, students tend to change their behaviors or attitudes (increasing or decreasing) in response to the behaviors of their friends (Blansky et al., 2013). Scholars agree that both selection and influence processes are relevant to explain the similarity between friends and group members (Kandel, 1978; Kiuru et al., 2010). In the case of the selection processes, there is evidence that adolescents tend to select friends based on their similar academic performance (Flashman, 2012; Shin \& Ryan, 2014), as well as to choose friends based on similar levels of doing homework and paying attention in class (Geven et al., 2013). In the case of social influence, research has shown that students tend to influence their levels in different educational outcomes, such as academic performance (Gremmen et al., 2017; Shin \& Ryan, 2014), paying attention in class and doing homework (Geven et al., 2013). 


\section{Academic Performance and Social Status}

During early adolescence, when social standing and belonging constitute main social goals (Ojanen et al., 2005), friends become relevant for social status. Peer relations constitute a relevant scenario to establish one's standing within the peer culture, where friends constitute a relevant marker of this social position (Dijkstra, Cillessen, et al., 2010). However, when addressing social status, two distinct forms of peer status must be acknowledged: popularity and social preference.

On the one hand, popularity has been conceived as an indicator of social standing, reputation, prestige, and visibility (Adler \& Adler, 1998), implying power and status within the peer group (Xie et al., 1999). Popularity-rather than social preference-is most strongly associated with social features, such as admiration, leadership, and social control (LaFontana \& Cillessen, 2002; Vaillancourt \& Hymel, 2006). However, while academic engagement is socially valued in elementary school, negative social and academic behaviors tend to be valued in middle school (Galván et al., 2011). Behaviors that express a sense of mature status but are not acceptable to be exhibited, such as aggressive behavior or substance use, are highly attractive for adolescents (Moffitt, 1993). This change produces that popular students are likely to perform risky behaviors to gain and maintain their social status (Mayeux et al., 2008) instead of focusing their attention on more positive behaviors, such as academic performance.

On the other hand, social preference (also called social acceptance) is generally operationalized as an indicator of likeability, expressing an affective dimension (LaFontana \& Cillessen, 2002). Typically, socially preferred youths are described as cooperative, kind, and good friends while still holding a positive standing within the hierarchy. Socially preferred individuals are academically motivated (e.g., high performance), prosocial and helpful to peers (Cillessen \& Berg, 2012; Torrente et al., 2014). Furthermore, socially preferred students tend to have reciprocated and high-quality friendships (Litwack et al., 2012; Parker \& Asher, 1993). High-quality friendships are associated with spending more time with peers, providing a suitable setting for peer influence. Also, socially preferred students are likely to emphasize and nurture their relationships with peers, teachers, and parents (Mayeux et al., 2011), creating a favorable environment for peer influence on academic performance.

The moderating role of social status in social selection and influence has been addressed in other studies (Berger \& Dijkstra, 2013; Dijkstra et al., 2011), showing that social status has a prominent effect in the selection process, even overcoming the effect of other variables, such as aggressive or prosocial behavior (Logis et al., 2013). Studies have started to consider social status as potentially affecting the association between friendship and academic performance (DeLay et al., 2015; Geven et al., 2013), as well as risky behaviors, such as alcohol use (Mathys et al.2013). A study by Rambaran et al. (2017) examined whether popularity and social preference of friends moderated selection and influence process in individual academic functioning (academic performance and truancy). The authors found that only social preference (not popularity) moderated peer influence in academic performance. Nevertheless, to our knowledge, no study has examined the extent that adolescents' own social status (popularity and social preference) moderate the influence of friends' academic performance.

Based on the previous literature on popularity and social preference, it was expected that socially preferred students would be more likely to become similar to their friends' academic performance than popular peers.

\section{The Present Study}

This study examined how individual academic performance is associated with friendships among fifth and sixth graders, testing the moderating effect of adolescents' own social status. Three research questions guided the present study: Is similarity in academic performance a significant factor in choosing friends? Do friends influence each other on their academic achievement levels? Is adolescents' own social status (popularity and social preference) a moderator for social influence regarding academic achievement? Over and above confirming previous studies on the social status between friends, it was hypothesized that: (1) students tend to befriend peers with similar academic performance; (2) students tend to assimilate their academic performance to that of their friends; and (3) socially preferred, compared to popular students, will be more likely to become similar to their friends' academic performance. 
PALACIOS AND BERGER

\section{Method}

\section{Design and Participants}

Longitudinal social network data included a convenience sample from 272 fifth and sixth graders (49\% female, age range: 9-12 years) from eight classrooms of two private-subsidized schools (four classrooms for each school) from middle class (according to the national socioeconomic classification used by the Chilean national system of educational evaluation based on parental schooling, family income, and the proportion of vulnerable students) in an urban area of Metropolitan Santiago, Chile. These schools were private, but received a public subsidy (pupil vouchers are paid to schools based on average attendance), representing the majority of the Chilean school population (54\% of the student population attended this type of schools in 2019 (Ministerio de Educación, 2021)). Chile is one of the countries with the highest levels of private participation in the school system in the Organisation for Economic Co-operation and Development countries (OECD, 2010). In general, public schools concentrate the most socially disadvantaged students, the middle-low and middle class attend private-subsidized schools, and the high class goes to private schools (García-Huidobro, 2007). The average class size was 34 (class size range: 29-42). Participants were assessed twice in the middle of the fall in 2012 and 2013.

\section{Variables and Measures}

\section{Friendship}

Participants were asked to nominate (unlimited) their classmates whom they considered their best friends. Adjacency matrices were created for each classroom on each assessment representing the friendship network, where friendship nominations were coded 1 and non-nominations were coded 0.

\section{Academic Performance}

The Academic subscale of the Teacher Interpersonal Competence Scale (Cairns et al., 1995) was used. Homeroom teachers rated their students' academic performance on a 1 to 7 scale on two descriptors: he/she is good at math, and he/she is good at [Spanish] language. The distribution was left-skewed, containing almost all of the grades in the range from 5.5 to 7, which is common in the Chilean education system. Based on the grades' distribution and RSiena requirements for dependent variables (Ripley et al., 2021), academic performance was recoded into six categories by intervals of three decimal points, except for the first category (see Table 1). This ensured us that the remaining scale had sufficient cases in each category $\left(1\right.$ low $\mathrm{AP}_{\mathrm{T} 1}=11.3 \% ; 2 \mathrm{~T}_{1}=21.3 \% ; 3 \mathrm{~T}_{1}=29.8 \% ; 44_{\mathrm{T} 1}=13.6 \% ; 5_{\mathrm{T} 1}=4.3 \% ; 6$ high $\left.\mathrm{AP}_{\mathrm{T} 1}=20 \%\right)$ for academic performance (time 1, $M=3.39, S D=1.62$; time $2, M=3.26$, $\mathrm{SD}=1.36$ ).

\section{Popularity and Social Preference}

Participants nominated classmates (unlimited) that they considered the most and the least popular, and whom they liked the most and the least. Proportion scores were the number of nominations received divided by the number of participants in the classroom minus 1 . Popularity was measured by calculating the difference score of the most popular minus the least popular, and social preference, by calculating the difference score of like the most, minus like the least (see Logis et al., 2013). To fulfill RSiena computation requirements, scores for popularity (time 1, $M=2.49, S D=1.14$ ) and social preference (time $1, M=2.53, S D=1.14$ ) were transformed into discrete ordinal scales of four categories (see Table 1). This procedure eases the interpretation of the variables and it is in line with studies that analyze social status within the RSiena framework (Logis et al., 2013; Shin, 2017).

\section{Procedure}

Signed parental consent was gathered for all participants. Surveys were self-administered during regular class hours through a group administration in the presence of trained research assistants. All instruments and procedures were approved by the Institutional Review Board of the host university and by the principals of the participating institutions. Participants were assured that their answers would be kept confidential and that they could stop participating at any time. 
Due to the features of longitudinal studies, students who entered schools in the second wave were excluded from the analyses. In addition, $10 \%$ of the data were missing due to unauthorized students and absence in the days of data collection. Attrition analyses showed that participants who were excluded did not differ significantly in any variable (academic performance time 1 and 2, popularity and social preference). The final sample included 240 students (48\% female). Students remained in the same classrooms over the course of the study.

\section{Analytic Strategy}

Statistical models for longitudinal social networks analysis in RSiena were used. RSiena allows simultaneously examining the selection and influence processes, considering the co-evolution of friendship networks and individual attributes while controlling for structural network effects (density, reciprocity, and transitivity) and covariates (e.g., social preference, popularity, gender). RSiena has some advantages over other methodologies addressing the dynamics of selection and social influence. First, it considers unobserved changes avoiding over-estimating effects of selection and influence. Second, it controls for structural network effects (implying that the presence of ties is highly dependent on the presence of other ties), and trends of behavioral variables (the behavioral trend could regress to the mean or polarize over time). Third, this approach uses all the network information and, thus, it needs a complete network sample design, which requires specifying the boundaries of the network (in this case, classrooms) where all participants of the network can report about their own relationships with each other. Finally, exogenous variables can be incorporated, both fixed (e.g., gender, ethnicity, socioeconomic status) or dynamic covariates (an attribute with at least two measurements over time). RSiena has been used to study selection and social influence processes in various phenomena, such as depression, substance consumption, weapon carrying, aggression, prosocial behavior, and academic performance, especially in North American and European populations (Light et al., 2013; Osgood et al., 2013; Veenstra et al., 2013).

Since the focus was on the general pattern of selection and influence effect on academic performance, rather than examining the variance between classrooms, the multi-group option was applied (combining classrooms and analyzing them simultaneously and assuming that parameters are identical across classroom networks) to gain sufficient power to detect influence effects (Ripley et al., 2021). This assumption was checked by running sienaTimetest, finding no significant differences ( $p$-values larger than 0.05) in the effects related to the hypotheses. These results mean that the combined results represent a meaningful aggregate.

Furthermore, there were included measures for the friendship changes and similarity of friends' academic performance. First, the Jaccard index as a measure of (friendship) ties stability between measurements. Second, the Geary's $\mathrm{C}$ as a measure of the similarity of friends' behavior in terms of academic performance (Steglich et al., 2010). This measure is an inverse indicator of network autocorrelation (i.e., a tendency for people who are closely related to each other to be similar on an individual characteristic), in which values close to one (Geary's $\mathrm{C}$ autocorrelation can reach values that are larger than 1) are expected under random pairing, while values close to zero indicate strong behavioral homogeneity.

Spearman correlations were conducted to examine the associations between academic performance, popularity, and social preference. Given that these variables were not normally distributed, Spearman correlations were employed. Also, independent samples $t$-tests were used to analyze whether there were significant differences between boys and girls on academic performance, popularity, and social preference.

\section{Model Specification and Effects Interpretation}

\section{Endogenous Networks Effects}

RSiena allows accounting for endogenous network structure effects, considering structural dynamics (e.g., reciprocity, transitivity) that are not explained by similarity-based selection or influence on academic performance. Basic network's structure effects were included: Density, representing the tendency of actors to establish friendship relations, and reciprocity, reflecting the tendency of reciprocated ties of the focal actor. Furthermore, in order to assess triadic closure, a measure of transitivity (that is, a friend of a friend is a friend), and cyclic closure were incorporated (which can be interpreted as generalized reciprocity). A positive transitivity effect, together with a negative cyclic closure effect, may be interpreted as a tendency toward local hierarchy.

Finally, two degree-related effects were added, indegree-popularity and outdegree-activity, to take into account the potential effect of the network positions of the actors on friendship selection. While a positive 
indegree-popularity effect implies that high indegrees reinforce themselves, which will lead to relatively high dispersion of the number of incoming nominations, a positive outdegree-activity effect, likewise, lead to relatively high dispersion of outgoing nominations (outdegrees) over time (Ripley et al., 2021).

\section{Covariates}

Studies show that both popularity and social preference (Berger \& Dijkstra, 2013; Logis et al., 2013) are central motives to select friends. Accordingly, the effects of popularity and social preference on selecting friends were examined by assessing whether participants who score similarly in any of these two variables tend to befriend (similarity effect), as well as whether participants who score higher are likely to send (ego effect) and/or receive (alter effect) more friendships nominations. Additionally, and considering that previous research has found that friendships tend to be comprised of same-sex members (Kindermann et al., 1996), the effects of gender similarity, ego, and alter on friendships were included.

\section{Academic Performance}

First, regarding the selection part of the model, the ego, alter, and similarity effects were included for academic performance. These effects refer to the tendency of high-achieving students to send (ego) and receive (alter) friendship nominations, as well as the tendency of students to befriend peers who exhibit similar levels of academic performance (academic performance similarity, hypothesis 1). Second, regarding the influence part of the model, the linear and quadratic shape effects were included. While the linear shape effect expresses a basic drive toward high values on academic performance, the quadratic shape effect reflects the effect of academic performance on itself. Both effects can be interpreted as a curvilinear function, expressing the results of inclinations and constraints for the possible values of academic performance, independent of other effects or explanatory mechanisms. Furthermore, the main effect of popularity and social preference on academic performance was incorporated. Positive values imply that actors with a higher value on each of these variables will have a stronger tendency toward high academic performance. Finally, effects for examining the influence of friendship on academic performance were added (academic performance average similarity, hypothesis 2), as well as the interaction of this effect with the level of popularity and social preference of ego (academic performance average similarity x popularity ego, and academic performance average similarity $\mathrm{x}$ social preference ego, hypothesis 3 ).

\section{Results}

\section{Descriptive Analysis}

Table 1 presents descriptive data on friendship ties, academic performance, and social status. Density, average degree, and the number of ties remained stable between assessments. Over the two periods, more friendships were finished (7\%) than created $(6 \%)$, with a small proportion of stable friendship ties $(4 \%)$. Moreover, the Jaccard index (0.22) suggests that friendship ties changed significantly between periods. Although this index is below the desired level of 0.30, it is enough to estimate the model (Ripley et al., 2021). Also, the average Geary's $\mathrm{C}$ for the two waves was 0.85 , denoting that friendship networks were not strongly structured on academic performance. Regarding academic performance, there was a slight decrease over time $\left(M_{\mathrm{T} 1}=3.39\right.$ and $\left.M_{\mathrm{T} 2}=3.26\right)$. Unlike time 1, in time 2 categories 4 and 5 (medium-high academic performance) increased notably, while categories 3 (intermediate academic performance) and 6 (high academic performance) decreased considerably (Table 1).

\section{Model Fit}

First, the model reached the suggested criteria about convergence, which recommends less than 0.25 in the overall maximum convergence and less than 0.10 for all the individual parameters (Ripley et al., 2021). Second, goodness of fitness tests to assess the adjustment of the model specification with respect to auxiliary social networks statistics were conducted (i.e., outdegree, indegree, geodesic distance, triadic census, academic performance distribution). These statistics are not explicitly fitted by a particular effect but are important network's features to represent the probability model. Goodness of fitness tests show whether the proposed model gives a good representation of these auxiliary statistics. The aggregated $p$-values (based on the Mahalanobis distance) for the base model were higher than 0.05, showing that outdegree, indegree, and 
academic performance distributions, which represent the simulated values for the end of the periods, represented well the observed information of the data (outdegree $p=0.334$; indegree $p=0.371$; geodesic distance $p=0.161$; triadic census $p=0.800$; academic performance $p=0.532$ ).

Table 1

Descriptives of Friendship Networks, Academic Performance, and Covariates

\begin{tabular}{|c|c|c|c|c|}
\hline & Time 1 & Time 2 & \multicolumn{2}{|c|}{ Time $1 \rightarrow$ Time 2} \\
\hline Friendship & & & Changes in friendship & \\
\hline Number of ties & 665 & 639 & Jaccard index ${ }^{a}$ & 0.22 \\
\hline Average degree & 3.25 & 2.82 & Hamming distance ${ }^{b}$ & 83.25 \\
\hline Density & 0.11 & 0.10 & Absence of tie $(0 \rightarrow 0)$ & $83 \%(n=4,654)$ \\
\hline Missing fraction & 0.15 & 0.06 & Creating tie $(0 \rightarrow 1)$ & $6 \%(n=329)$ \\
\hline Network autocorrelation & & & Resolving tie $(1 \rightarrow 0)$ & $7 \%(n=415)$ \\
\hline Geary's C academic performance & 0.72 & 0.97 & Stable tie $(1 \rightarrow 1)$ & $4 \%(n=211)$ \\
\hline Academic performance & & & Changes in academic pe & rmance \\
\hline Category $1(<5.5)$ & $11.1 \%$ & $12.6 \%$ & Stables actors & $41.1 \%$ \\
\hline Category $2(5.6-5.8)$ & $21.3 \%$ & $21.0 \%$ & Decreasing actors & $33.9 \%$ \\
\hline Category $3(5.9-6.1)$ & $29.8 \%$ & $17.3 \%$ & Increasing actors & $24.8 \%$ \\
\hline Category $4(6.2-6.4)$ & $13.6 \%$ & $26.2 \%$ & & \\
\hline Category $5(6.5-6.7)$ & $4.3 \%$ & $22.4 \%$ & & \\
\hline Category $6(6.8-7)$ & $20.0 \%$ & $0.5 \%$ & & \\
\hline Covariates values & $\begin{array}{l}\text { Popularity } \\
\text { Time } 1\end{array}$ & $\begin{array}{c}\text { Social Preference } \\
\text { Time } 1\end{array}$ & Gender & \\
\hline Category 1 & $27 \%$ & $25 \%$ & $52 \%$ (male) & \\
\hline Category 2 & $24 \%$ & $23 \%$ & $48 \%$ (female) & \\
\hline Category 3 & $24 \%$ & $26 \%$ & & \\
\hline Category 4 & $26 \%$ & $26 \%$ & & \\
\hline
\end{tabular}

Note. ${ }^{\text {a }}$ The Jaccard index is a measure of stability, calculated as a function of the number of ties present at both observation points, as well as the number of ties added and dropped between the two observation points; b The Hamming distance shows the distance between successively observed networks (the number of tie variables that differ between measurement points). $n=240,8$ classrooms.

The Table 2 shows the Spearman's rank correlations among variables. As expected, academic performance was stable over time. It was found positive associations between popularity and social preference. These correlations were similar for both genders, except for the positive association between academic performance (time 1) and social preference for girls, which was non-significant for boys. In addition, variables' means were compared by gender. T-tests showed non differences between boys and girls for social preference, $t(238)=-1.96, p=0.051$, popularity, $t(238)=1.59, p=0.112$, and academic performance at time 1 , $t(233)=-1.45, p=0.146$, and time $2, t(212)=-1.92, p=0.056$.

Table 2

Spearman's Rank Correlation Between Academic Performance and Social Status by Gender

\begin{tabular}{llccc}
\hline & 1 & 2 & 3 & 4 \\
\hline 1. Academic performance t1 & - & $0.44^{*}$ & 0.10 & 0.12 \\
2. Academic performance t2 & $0.28^{*}$ & - & -0.04 & 0.06 \\
3. Popularity t1 & 0.13 & -0.03 & - & $0.35^{*}$ \\
4. Social preference t1 & $0.27^{*}$ & -0.03 & $0.32^{*}$ & - \\
\hline
\end{tabular}

Note. $n=240,8$ classrooms. Upper diagonal matrix presents results for boys $(n=125)$, while lower diagonal presents results for girls $(n=115)$; ${ }^{*} p<0.01$. 


\section{Social Networks Analysis}

The results for the social network analyses are presented in Table 3. The model contains structural network effects, academic performance, and covariate effects, including selection (academic performance's ego, alter and similarity) and influence (academic performance average similarity) effects.

Table 3

RSiena Estimates Parameters of Academic Performance (Time 1 and Time 2)

\begin{tabular}{|c|c|c|c|}
\hline \multirow{2}{*}{ Effect } & \multicolumn{3}{|c|}{ Model } \\
\hline & Estimate & $p$ & $S E$ \\
\hline \multicolumn{4}{|l|}{ Friendship dynamics } \\
\hline \multicolumn{4}{|l|}{ Effects of network structure } \\
\hline Outdegree & -1.13 & $<0.001$ & 0.32 \\
\hline Reciprocity & 1.54 & $<0.001$ & 0.19 \\
\hline Transitivity $^{a}$ & 1.36 & $<0.001$ & 0.19 \\
\hline Cyclic closure $^{b}$ & -0.19 & 0.336 & 0.20 \\
\hline Indegree popularity (squared) & -0.36 & 0.004 & 0.12 \\
\hline Outdegree activity (squared) & -0.30 & $<0.001$ & 0.08 \\
\hline \multicolumn{4}{|l|}{ Effects of academic performance } \\
\hline Academic performance alter & 0.04 & 0.512 & 0.06 \\
\hline Academic performance ego & 0.01 & 0.778 & 0.06 \\
\hline Academic performance similarity $(\mathrm{H} 1)$ & 0.29 & 0.460 & 0.40 \\
\hline \multicolumn{4}{|l|}{ Effects of covariates } \\
\hline Gender (male) alter & 0.01 & 0.929 & 0.09 \\
\hline Gender (male) ego & -0.13 & 0.136 & 0.09 \\
\hline Same gender & 0.57 & $<0.001$ & 0.07 \\
\hline Popularity alter & 0.08 & 0.028 & 0.03 \\
\hline Popularity ego & -0.07 & 0.065 & 0.04 \\
\hline Popularity similarity & 0.17 & 0.008 & 0.06 \\
\hline Social preference alter & 0.08 & 0.050 & 0.04 \\
\hline Social preference ego & 0.01 & 0.782 & 0.04 \\
\hline Social preference similarity & 0.07 & 0.268 & 0.07 \\
\hline \multicolumn{4}{|l|}{ Academic performance dynamics } \\
\hline \multicolumn{4}{|l|}{ Shape effects } \\
\hline Academic performance linear shape & -0.06 & 0.176 & 0.05 \\
\hline Academic performance quadratic shape & -0.04 & 0.403 & 0.05 \\
\hline \multicolumn{4}{|l|}{ Effects of covariates } \\
\hline Popularity & -0.03 & 0.482 & 0.04 \\
\hline Social preference & 0.02 & 0.613 & 0.05 \\
\hline \multicolumn{4}{|l|}{ Effects of friends' behaviors (social influence) } \\
\hline Academic performance average similarity (H2) & 3.95 & 0.015 & 1.61 \\
\hline \multicolumn{4}{|l|}{ Moderators of social influence } \\
\hline Academic performance average similarity x popularity ego (H3) & -0.26 & 0.796 & 1.03 \\
\hline Academic performance average similarity x social preference ego (H3) & 2.44 & 0.055 & 1.27 \\
\hline
\end{tabular}

Note. $n=240,8$ classrooms. Statistical significance of each parameter is determined by dividing the estimate by its standard error and comparing it to a normalized $z$-distribution. ${ }^{a} \mathrm{~A}$ gwesp $F F$ version was included, which indicates the number of nodes $j$ such that $i \rightarrow j$ and there are exactly $k$ other nodes $h$ for which there is the two-path $i \rightarrow h \rightarrow j$. ${ }^{\mathrm{b}} \mathrm{A}$ gwespBB version was included, which indicates the number of nodes $j$ such that $i \rightarrow j$ and there are exactly $k$ other nodes $h$ for which there is the two-path $i \leftarrow h \leftarrow j$.

\section{Structural Network Effects}

In the structural part of the model, it was observed significant negative effects for density (students nominated less than half of their classmates as friends) and positive effects for reciprocity (students tend to establish reciprocal friendships over time). Also, it was found a significant positive effect of transitivity (friends of friends tend to become friends over time) and a negative but non-significant effect of cyclic closure. 
Lastly, both outdegree-activity and indegree-popularity effects were significantly negative, suggesting that actors with a high number of given nominations are less likely to send additional nominations and students with a high number of incoming nominations are less likely to attract new ties over time, respectively.

\section{Covariates}

With respect to the covariates, it was found that popular students showed a tendency to nominate fewer students as friends (negative popularity ego) and to receive more friendships nominations (positive popularity alter), expressing their influential and prestigious position. In addition, students with similar popularity were more likely to nominate each other as a friend (positive popularity similarity). Likewise, socially preferred students tended to receive more nominations as friends (positive social preference alter) and were more likely to nominate each other as a friend (positive social preference similarity). Furthermore, friendships were more likely to occur among same-gender peers (positive same gender). Regarding the role of academic performance in friendship selection, academic performance did not affect nominating or being nominated as a friend (non-significant academic performance ego and alter effects). Moreover, a tendency of students befriending classmates with similar academic performance was not found (non-significant academic performance similarity), rejecting hypothesis 1 . To ensure that this result was consistent between different model specifications, additional analyses without including popularity and social preference effects in the model were conducted. The results (available upon request) indicated that the academic performance similarity effect remained not significant.

\section{Academic Performance Dynamics}

Non-significant linear and quadratic shape effects were found, indicating that the change in academic performance did not follow a specific pattern over the two assessments. Next, the influence of academic performance between friends was observed, showing a tendency of students to become similar to their friends' academic performance (positive academic performance average similarity), supporting hypothesis 2. Regarding adolescents' own social status' moderating the academic performance's influence, a significant positive effect of social preference was observed (positive academic performance average similarity x social preference), suggesting that socially preferred students were more likely to become similar to their friends' academic performance, in comparison with students with lower levels of social preference (supporting hypothesis 3). On the contrary, it was not observed a moderation of popularity in academic performance influence (non-significant academic performance average similarity x popularity).

\section{Discussion and Conclusions}

Using longitudinal social network analysis, this study examined how friendships may affect academic performance, but also how individual academic performance can shape friendships. Moreover, and departing from the extant literature on peer relations and social status, this study assessed the moderating role of popularity and social preference might have on the influence of academic performance.

\section{Friendship Selection Based on Academic Performance Similarity}

The results did not support the selection hypothesis. Namely, friendship nominations were not driven by students' similarity in academic performance. Interestingly, previous studies have found that younger children ( $3^{\text {rd }}$ and $4^{\text {th }}$ graders) tend to consider academic performance as a relevant variable to choose friends (Chen et al., 2003; Palacios \& Berger, 2015), suggesting that academic success may constitute a socially valued attribute in elementary school. During these grades, the orientation towards peers is still not that strong and, thus, the value that teachers and parents attribute to academic performance may drive this social value fostering students to select as friends those who meet their academic expectations (Wentzel, 1999). Taken together with the results, it is possible that during fifth and sixth grades may be a shift regarding the socially valued attributes that drive friendship selection, possibly fostered by an increasing orientation towards peers. As a result, other attributes, such as aggression and antisocial behaviors, which constitute effective signals of defiance to adults, begin to be associated with social status and, therefore, may become more salient in choosing friends (Galván et al., 2011; Moffitt, 1993). 


\section{Social Influence on Academic Performance}

This study found evidence for the influence hypothesis: Students tended to change their academic performance resembling their friends' average academic performance. This could be due to two reasons. First, peers become increasingly important for adolescents as a context for identity development and sharing relevant experiences and may fulfill the need for affiliation and approval (Hartup \& Stevens, 1997). At this stage, peer influence is more likely to occur, because adolescents begin to spend more time with peers, considering them as a source of identity, approval, and advice (Bukowski et al., 2000). Second, increasing opportunities for interaction and academic work between students, where they can learn and imitate the study habits and skills of their classmates, may foster social influence. For instance, Newcomb and Bagwell (1995) argue that the collaborating process on an academic task with a high-achieving friend can be more engaging and motivating than with average-achieving peers and, thus, may foster the internalization of positive learning goals promoted by high-achieving friends. In this line, research has shown that higherachieving friends influenced the mathematical reasoning of lower-achieving friends, but not the reverse (DeLay et al., 2015). Furthermore, future studies should examine potential mechanisms for peer influence on academic performance, such as modeling academic-oriented behaviors (Kandel \& Andrews, 1987) and peer pressure toward achievement (Brown et al., 1986).

\section{The Moderating Role of Social Status in Academic Performance's Influence}

An interesting result of this study is that social influence on academic performance is related to adolescents' own social status. Social influence was moderated by social preference, but not by popularity. This means that socially preferred students would be more influenced by their friends' academic performance than other students with lower levels of social preference. These results are in line with findings suggesting that friends' social preference moderated individual academic achievement's influence (Rambaran et al., 2017). The results suggest that certain features of socially preferred students, such as cooperation, reciprocity, and high-quality friendships, would facilitate the influence on academic performance. In other words, the influence of academic performance would be more likely to occur not only when friends are socially preferred, but also when the focal actor (ego) is socially preferred. Furthermore, this finding is also consistent with the positive relationship between social preference and prosocial behavior (Becker \& Luthar, 2007), suggesting that positive behavior (e.g., prosocial behavior) is likely to result in supportive interactions with peers, including interest in enhancing personal relationships and concern for others (Twenge et al., 2007), as well as provisions of academic help and positive feedback (Wentzel, 2015).

Conversely, and compared to socially preferred peers, popular students seem to be less sensitive to their friends' academic performance. One explanation is that the latter group of students mainly focus their attention on salient goals, such as aggressive and deviant behavior (Andreou, 2006; Prinstein \& Cillessen, 2003), substance use (Mayeux et al., 2008), and sports (Shakib et al., 2011). For example, research has found that popularity moderated peer influence in truancy (Rambaran et al., 2017) and dropping out of school (Traag, Lubbers \& van der Velden, 2012). In this regard, upcoming studies could test whether adolescents' and friends' social status moderates social influence on other salient behaviors, such as aggressive and prosocial behavior or sports.

\section{Future Research and Limitations}

From a conceptual standpoint, and considering the opportunities for educational interventions, the results call attention to the role that peer relations may have in academic performance. Contrary to understanding academic achievement as a result of fixed abilities (Blackwell et al., 2007), the possibility of change, in this case as a function of friends' academic achievement, stresses its malleability and opens an interesting field for promoting academic and, more broadly, personal development. For instance, several studies have shown that ethnic, social, and academic diversity in the classroom positively impacts students' educational development (Gottfried, 2014; Sacerdote, 2001). Furthermore, teachers could play an important role by providing opportunities for interaction between students, setting rules on desirable behaviors and organizing sitting arrangements. These decisions have potential consequences for the social and academic development of their students (Farmer et al., 2011; Gest \& Rodkin, 2011). In this sense, promoting diverse friendships and a dynamic peer network may offer adolescents a broader social context for increasing their mutual influence. This influence, however, may refer to both positive and negative traits and behaviors and, 
therefore, teachers and school administrators should promote and make visible positive characteristics and foster relationships around them.

This study has some limitations that should be acknowledged. The sample is relatively small and comes from two schools. Also, the long interval between assessments may mask short-term friendship dynamics. For instance, there is some evidence that the influence of academic performance is more likely to occur within the academic year, mostly when students do not know each other at the beginning of the year (Gremmen et al., 2017). Seemingly, a unique and indirect measure of academic performance (teacher academic perception) was used. Also, to better understand the nature and extent of selection and influence processes on academic performance, future studies could include not only the duration and quality of friendships, but also academic relationships, for example, who study with whom in classrooms (Palacios et al., 2019). Finally, this study featured a sample from Chile. Most research on adolescents' peer relations has been conducted in the United States and Europe. Accordingly, some considerations should be taken into account when addressing this sample. Classmates remain together from $1^{\text {st }}$ to $12^{\text {th }}$ grade; therefore, classes tend to exhibit a high peer group stability and a fixed peer culture. Also, the ethnic composition of the Chilean society is quite homogeneous, with $91 \%$ of the population self-identifying as white or mixed-race with European ascendancy (Ministerio de Desarrollo Social, 2017). In spite of these particularities, research on adolescent peer relationships with Chilean samples has shown similar patterns to those found in the United States and European youth for several variables, such as aggression (Dijkstra et al., 2011), friendships and antipathies (Berger \& Dijkstra, 2013; Rambaran et al., 2015), and victimization (Cuadros \& Berger, 2016; Hodges et al., 1997; Hodges \& Perry, 1999).

Despite these limitations, by incorporating relevant social status variables (adolescents' popularity and social preference) as moderators of friends' influence on academic performance, this study contributes to broadening the understanding of peer relations in adolescence and opens a promising research area that could inform educational and developmental interventions. Developing research in diverse international contexts may help broaden and validate the accumulated evidence on the relationship between peer dynamics and academic performance, showing the normative character of selection processes regarding academic performance and social status in friendship selection.

\section{References}

Adler, P. A., \& Adler, P. (1998). Peer power: Preadolescent culture and identity. Rutgers University Press.

Andreou, E. (2006). Social preference, perceived popularity and social intelligence: Relations to overt and relational aggression. School Psychology International, 27(3), 339-351. https://doi.org/10.1177/0143034306067286

Becker, B. E., \& Luthar, S. S. (2007). Peer-perceived admiration and social preference: Contextual correlates of positive peer regard among suburban and urban adolescents. Journal of Research on Adolescence, 17(1), 117-144. https://doi.org/10.1111/j.1532-7795.2007.00514.x

Berger, C., \& Dijkstra, J. K. (2013). Competition, envy, or snobbism? How popularity and friendships shape antipathy networks of adolescents. Journal of Research on Adolescence, 23(3), 586-595. https://doi.org/10.1111/jora.12048

Berger, C., \& Rodkin, P. C. (2012). Group influences on individual aggression and prosociality: Early adolescents who change peer affiliations. Social Development, 21(2), 396-413. https://doi.org/10.1111/j.1467-9507.2011.00628.x

Blackwell, L. S., Trzesniewski, K. H., \& Dweck, C. S. (2007). Implicit theories of intelligence predict achievement across an adolescent transition: A longitudinal study and an intervention. Child Development, 78(1), 246-263. https://doi.org/10.1111/j.1467-8624.2007.00995.x

Blansky, D., Kavanaugh, C., Boothroyd, C., Benson, B., Gallagher, J., Endress, J., \& Sayama, H. (2013). Spread of academic success in a high school social network. PLoS ONE, 8(2), e55944. https://doi.org/10.1371/journal.pone.0055944

Brown, B. B., Clasen, D. R., \& Eicher, S. A. (1986). Perceptions of peer pressure, peer conformity dispositions, and self-reported behavior among adolescents. Developmental Psychology, 22(4), 521-530. https://doi.org/10.1037/0012-1649.22.4.521

Buchmann, C., \& Dalton, B. (2002). Interpersonal influences and educational aspirations in 12 countries: The importance of institutional context. Sociology of Education, 75(2), 99-122. https://doi.org/10.2307/3090287

Bukowski, W. M., \& Sippola, L. K. (2005). Friendship and development: Putting the most human relationship in its place. New Directions for Child and Adolescent Development, 2005(109), 91-98. https://doi.org/10.1002/cd.141

Bukowski, W. M., Sippola, L. K., \& Newcomb, A. F. (2000). Variations in patterns of attraction of same- and other-sex peers during early adolescence. Developmental Psychology, 36(2), 147-154. https://doi.org/10.1037/0012-1649.36.2.147

Cairns, R. B., Leung, M. -C., Gest, S. D., \& Cairns, B. D. (1995). A brief method for assessing social development: Structure, reliability, stability, and developmental validity of the interpersonal competence scale. Behaviour Research and Therapy, 33(6), 725-736. https://doi.org/10.1016/0005-7967(95)00004-H

Chen, Q., Hughes, J. N., Liew, J., \& Kwok, O. -M. (2010). Joint contributions of peer acceptance and peer academic reputation to achievement in academically at-risk children: Mediating processes. Journal of Applied Developmental Psychology, 31(6), 448-459. https://doi.org/10.1016/j.appdev.2010.09.001

Chen, X., Chang, L., \& He, Y. (2003). The peer group as a context: Mediating and moderating effects on relations between academic achievement and social functioning in chinese children. Child Development, 74(3), 710-727. https://doi.org/10.1111/1467-8624.00564

Cillessen, A. H. N., \& Berg, Y. H. M. v. d. (2012). Popularity and school adjustment. In A. M. Ryan, \& G. W. Ladd (Eds.), Peer relationships and adjustment at school (pp. 135-164). IAP Information Age Publishing.

Cuadros, O., \& Berger, C. (2016). The protective role of friendship quality on the wellbeing of adolescents victimized by peers. Journal of Youth and Adolescence, 45(9), 1877-1888. https://doi.org/10.1007/s10964-016-0504-4 
DeLay, D., Laursen, B., Kiuru, N., Poikkeus, A.n-M., Aunola, K., \& Nurmi, J.n-E. (2015). Stable same-sex friendships with higher achieving partners promote mathematical reasoning in lower achieving primary school children. British Journal of Developmental Psychology, 33(4), 519-532. https://doi.org/10.1111/bjdp.12117

Dijkstra, J. K., Berger, C., \& Lindenberg, S. (2011). Do physical and relational aggression explain adolescents' friendship selection? The competing roles of network characteristics, gender, and social status. Aggressive Behavior, 37(5), 417-429. https://doi.org/10.1002/ab.20402

Dijkstra, J. K., Cillessen, A. H. N., Lindenberg, S., \& Veenstra, R. (2010). Basking in reflected glory and its limits: Why adolescents hang out with popular peers. Journal of Research on Adolescence, 20(4), 942-958. https://doi.org/10.1111/j.1532-7795.2010.00671.x

Dijkstra, J. K., Lindenberg, S., Veenstra, R., Steglich, C., Isaacs, J., Card, N. A., \& Hodges, E. V. E. (2010). Influence and selection processes in weapon carrying during adolescence: The roles of status, aggression, and vulnerability. Criminology, 48(1), 187-220. https://doi.org/10.1111/j.1745-9125.2010.00183.x

Dishion, T. J., \& Dodge, K. A. (2005). Peer contagion in interventions for children and adolescents: Moving towards an understanding of the ecology and dynamics of change. Journal of Abnormal Child Psychology, 33(3), 395-400. https://doi.org/10.1007/s10802-005-3579-z

Eccles, J. S. (2004). Schools, academic motivation, and stage-environment fit. In R. M. Lerner \& L. Steinberg (Eds.), Handbook of adolescent psychology: Second edition (pp. 125-153). John Wiley \& Sons. https://doi.org/10.1002/9780471726746.ch5

Ellis, W. E., \& Zarbatany, L. (2007). Peer group status as a moderator of group influence on children's deviant, aggressive, and prosocial behavior. Child Development, 78(4), 1240-1254. https://doi.org/10.1111/j.1467-8624.2007.01063.x

Espelage, D. L., Holt, M. K., \& Henkel, R. R. (2003). Examination of peer-group contextual effects on aggression during early adolescence. Child Development, 74(1), 205-220. https://doi.org/10.1111/1467-8624.00531

Farmer, T. W., Farmer, E. M. Z., Estell, D. B., \& Hutchins, B. C. (2007). The developmental dynamics of aggression and the prevention of school violence. Journal of Emotional and Behavioral Disorders, 15(4), 197-208. https://doi.org/10.1177/10634266070150040201

Farmer, T. W., Lines, M. M, \& Hamm, J. V. (2011). Revealing the invisible hand: The role of teachers in children's peer experiences. Journal of Applied Developmental Psychology, 32(5), 247-256. https://doi.org/10.1016/j.appdev.2011.04.006

Flashman, J. (2012). Academic achievement and its impact on friend dynamics. Sociology of Education, 85(1), 61-80. https://doi.org/10.1177/0038040711417014

Galván, A., Spatzier, A., \& Juvonen, J. (2011). Perceived norms and social values to capture school culture in elementary and middle school. Journal of Applied Developmental Psychology, 32(6), 346-353. https://doi.org/10.1016/j.appdev.2011.08.005

García-Huidobro, J. E. (2007). La "selección de alumnos" en la Ley General de Educación. Revista Docencia, 32, 20-27. http://revistadocencia.cl/sitio/wp-content/uploads/2021/12/docencia_32.pdf

Gest, S. D., \& Rodkin, P. C. (2011). Teaching practices and elementary classroom peer ecologies. Journal of Applied Developmental Psychology, 32(5), 288-296. https://doi.org/10.1016/j.appdev.2011.02.004

Geven, S., Weesie, J., \& van Tubergen, F. (2013). The influence of friends on adolescents' behavior problems at school: The role of ego, alter and dyadic characteristics. Social Networks, 35(4), 583-592. https://doi.org/10.1016/j.socnet.2013.08.002

Gottfried, M. A. (2014). The positive peer effects of classroom diversity: Exploring the relationship between english language learner classmates and socioemotional skills in early elementary school. The Elementary School Journal, 115(1), 22-48. https://doi.org/10.1086/676948

Gremmen, M. C., Dijkstra, J. K., Steglich, C., \& Veenstra, R. (2017). First selection, then influence: Developmental differences in friendship dynamics regarding academic achievement. Developmental Psychology, 53(7), 1356-1370. https://doi.org/10.1037/dev0000314

Hartup, W. W., \& Stevens, N. (1997). Friendships and adaptation in the life course. Psychological Bulletin, 121(3), 355-370. https://doi.org/10.1037/0033-2909.121.3.355

Haselager, G. J. T., Hartup, W. W., van Lieshout, C. F. M., \& Riksen-Walraven, J. M. A. (1998). Similarities between friends and nonfriends in middle childhood. Child Development, 69(4), 1198-1208. https://doi.org/10.1111/j.1467-8624.1998.tb06167.x

Hodges, E. V. E., Malone, M. J., \& Perry, D. G. (1997). Individual risk and social risk as interacting determinants of victimization in the peer group. Developmental Psychology, 33(6), 1032-1039. https://doi.org/10.1037/0012-1649.33.6.1032

Hodges, E. V. E., \& Perry, D. G. (1999). Personal and interpersonal antecedents and consequences of victimization by peers. Journal of Personality and Social Psychology, 76(4), 677-685. https://doi.org/10.1037/0022-3514.76.4.677

Johnson, K. A. (2000). The peer effect on academic achievement among public elementary school students. The Heritage Foundation. http://thf_media.s3.amazonaws.com/2000/pdf/cda00-06.pdf

Kandel, D. B. (1978). Homophily, selection, and socialization in adolescent friendships. American Journal of Sociology, 84(2), 427-436. https://doi.org/10.1086/226792

Kandel, D. B., \& Andrews, K. (1987). Processes of adolescent socialization by parents and peers. Substance Use \& Misuse, 22(4), 319342. https://doi.org/10.3109/10826088709027433

Kindermann, T. A. (1993). Natural peer groups as contexts for individual development: The case of children's motivation in school. Developmental Psychology, 29(6), 970-977. https://doi.org/10.1037/0012-1649.29.6.970

Kindermann, T. A. (2007). Effects of naturally existing peer groups on changes in academic engagement in a cohort of sixth graders. Child Development, 78(4), 1186-1203. https://doi.org/10.1111/j.1467-8624.2007.01060.x

Kindermann, T. A., McCollan, T. L., \& Gibson Jr., E. (1996). Peer networks and students' classroom engagement during childhood and adolescence. In J. Juvonen, \& K. R. Wentzel (Eds.), Social motivation: Understanding children's school adjustment (pp. 279-312). Cambridge University Press. https://doi.org/10.1017/CBO9780511571190.014

Kiuru, N., Burk, W. J., Laursen, B., Salmela-Aro, K., \& Nurmi, J. -E. (2010). Pressure to drink but not to smoke: Disentangling selection and socialization in adolescent peer networks and peer groups. Journal of Adolescence, 33(6), 801-812. https://doi.org/10.1016/j.adolescence.2010.07.006

LaFontana, K. M., \& Cillessen, A. H. N. (2002). Children's perceptions of popular and unpopular peers: A multimethod assessment. Developmental Psychology, 38(5), 635-647. https://doi.org/10.1037/0012-1649.38.5.635

Light, J. M., Greenan, C. C., Rusby, J. C., Nies, K. M., \& Snijders, T. A. B. (2013). Onset to first alcohol use in early adolescence: A network diffusion model. Journal of Research on Adolescence, 23(3), 487-499. https://doi.org/10.1111/jora.12064

Litwack, S. D., Aikins, J. W., \& Cillessen, A. H. N. (2012). The distinct roles of sociometric and perceived popularity in friendship: Implications for adolescent depressive affect and self-esteem. The Journal of Early Adolescence, 32(2), 226-251. https://doi.org/10.1177/0272431610387142

Logis, H. A., Rodkin, P. C., Gest, S. D., \& Ahn, H. -J. (2013). Popularity as an organizing factor of preadolescent friendship networks: Beyond prosocial and aggressive behavior. Journal of Research on Adolescence, 23(3), 413-423. https://doi.org/10.1111/jora.12033 
Lomi, A., Snijders, T. A. B., Steglich, C. E. G., \& Torló, V. J. (2011). Why are some more peer than others? Evidence from a longitudinal study of social networks and individual academic performance. Social Science Research, 40(6), 1506-1520. https://doi.org/10.1016/j.ssresearch.2011.06.010

Marjoribanks, K. (1998). Family capital, children's individual attributes, and adolescents' aspirations: A follow-up analysis. The Journal of Psychology, 132(3), 328-336. https://doi.org/10.1080/00223989809599171

Mathys, C., Burk, W. J., \& Cillessen, A. H. N. (2013). Popularity as a moderator of peer selection and socialization of adolescent alcohol, marijuana, and tobacco use. Journal of Research on Adolescence, 23(3), 513-523. https://doi.org/10.1111/jora.12031

Mayeux, L., Houser, J. J., \& Dyches, K. D. (2011). Social acceptance and popularity: Two distinct forms of peer status. In A. H. N. Cillessen, D. Schwartz, \& L. Mayeux (Eds.), Popularity in the peer system (pp. 79-102). Guilford Press.

Mayeux, L., Sandstrom, M. J., \& Cillessen, A. H. N. (2008). Is being popular a risky proposition? Journal of Research on Adolescence, 18(1), 49-74. https://doi.org/10.1111/j.1532-7795.2008.00550.x

Ministerio de Desarrollo Social. (2017). Informe de desarrollo social 2017. Gobierno de Chile. http://www.desarrollosocialyfamilia.gob.cl/pdf/upload/IDS2017.pdf

Ministerio de Educación (2021). Apuntes 12. Gobierno de Chile. https://centroestudios.mineduc.cl/wpcontent/uploads/sites/100/2021/03/APUNTES-12_2021.pdf

Moffitt, T. E. (1993). Adolescence-limited and life-course-persistent antisocial behavior: A developmental taxonomy. Psychological Review, 100(4), 674-701. https://doi.org/10.1037/0033-295X.100.4.674

Newcomb, A. F., \& Bagwell, C. L. (1995). Children's friendship relations: A meta-analytic review. Psychological Bulletin, 117(2), 306347. https://doi.org/10.1037/0033-2909.117.2.306

Ojanen, T., Grönroos, M., \& Salmivalli, C. (2005). An interpersonal circumplex model of children's social goals: Links with peer-reported behavior and sociometric status. Developmental Psychology, 41(5), 699-710. https://doi.org/10.1037/0012-1649.41.5.699

Organisation for Economic Co-operation and Development. (2010). Education at a glance 2010: OECD indicators. https://doi.org/10.1787/eag-2010-en

Osgood, D. W., Ragan, D. T., Wallace, L., Gest, S. D., Feinberg, M. E., \& Moody, J. (2013). Peers and the emergence of alcohol use: Influence and selection processes in adolescent friendship networks. Journal of Research on Adolescence, 23(3), 500-512. https://doi.org/10.1111/jora.12059

Palacios, D., \& Berger, C. (2015). Are good students desirable friends? Evidence for friendship selection among elementary students. Estudios de Psicología, 36(2), 496-508. https://doi.org/10.1080/02109395.2015.1028729

Palacios, D., Dijkstra, J. K., Villalobos, C., Treviño, E., Berger, C., Huisman, M., \& Veenstra, R. (2019). Classroom ability composition and the role of academic performance and school misconduct in the formation of academic and friendship networks. Journal of School Psychology, 74, 58-73. https://doi.org/10.1016/j.jsp.2019.05.006

Parker, J. G., \& Asher, S. R. (1993). Friendship and friendship quality in middle childhood: Links with peer group acceptance and feelings of loneliness and social dissatisfaction. Developmental Psychology, 29(4), 611-621. https://doi.org/10.1037/0012-1649.29.4.611

Piehler, T. F., \& Dishion, T. J. (2007). Interpersonal dynamics within adolescent friendships: Dyadic mutuality, deviant talk, and patterns of antisocial behavior. Child Development, 78(5), 1611-1624. https://doi.org/10.1111/j.1467-8624.2007.01086.x

Poulin, F., \& Boivin, M. (2000). Reactive and proactive aggression: Evidence of a two-factor model. Psychological Assessment, 12(2), 115122. https://doi.org/10.1037/1040-3590.12.2.115

Prinstein, M. J., \& Cillessen, A. H. N. (2003). Forms and functions of adolescent peer aggression associated with high levels of peer status. Merrill-Palmer Quarterly, 49(3), 310-342. https://doi.org/10.1353/mpq.2003.0015

Rambaran, J. A., Dijkstra, J. K., Munniksma, A., \& Cillessen, A. H. N. (2015). The development of adolescents' friendships and antipathies: A longitudinal multivariate network test of balance theory. Social Networks, 43, 162-176. https://doi.org/10.1016/j.socnet.2015.05.003

Rambaran, J. A., Hopmeyer, A., Schwartz, D., Steglich, C., Badaly, D., \& Veenstra, R. (2017). Academic functioning and peer influences: A short-term longitudinal study of network-behavior dynamics in middle adolescence. Child Development, 88(2), 523-543. https://doi.org/10.1111/cdev.12611

Ripley, R. M., Snijders, T. A. B., Boda, Z., Vörös, A., \& Preciado, P. (2021). Manual for RSiena [Computer software]. University of Oxford, Department of Statistics \& Nuffield College. http://www.stats.ox.ac.uk/ snijders/siena/RSiena_Manual.pdf

Rodkin, P. C., \& Ryan, A. M. (2012). Child and adolescent peer relations in educational context. In K. R. Harris, S. Graham, T. Urdan, S. Graham, J. M. Royer, \& M. Zeidner (Eds.), APA educational psychology handbook, Vol. 2: Individual differences and cultural and contextual factors (pp. 363-389). American Psychological Association. https://doi.org/10.1037/13274-015

Rubin, K. H., Bukowski, W. M., \& Parker, J. G. (1998). Peer interactions, relationships, and groups. In W. Damon \& N. Eisenberg (Eds.), Handbook of child psychology. Vol. 3: Social, emotional, and personality development (5 ${ }^{\text {th }}$ ed.) (pp. 619-700). John Wiley \& Sons. https://doi.org/10.1002/9780470147658.CHPSY0310

Ryan, A. M. (2001). The peer group as a context for the development of young adolescent motivation and achievement. Child Development, 72(4), 1135-1150. https://doi.org/10.1111/1467-8624.00338

Sacerdote, B. (2001). Peer effects with random assignment: results for dartmouth roommates. The Quarterly Journal of Economics, 116(2), 681-704. https://doi.org/10.1162/00335530151144131

Shakib, S., Veliz, P., Dunbar, M. D., \& Sabo, D. (2011). Athletics as a source for social status among youth: Examining variation by gender, race/ethnicity, and socioeconomic status. Sociology of Sport Journal, 28(3), 303-328. https://doi.org/10.1123/ssj.28.3.303

Shin, H. (2017). Friendship dynamics of adolescent aggression, prosocial behavior, and social status: The moderating role of gender. Journal of Youth and Adolescence, 46(11), 2305-2320. https://doi.org/10.1007/s10964-017-0702-8

Shin, H., \& Ryan, A. M. (2014). Early adolescent friendships and academic adjustment: Examining selection and influence processes with longitudinal social network analysis. Developmental Psychology, 50(11), 2462-2472. https://doi.org/10.1037/a0037922

Snijders, T. A. B., van de Bunt, G. G., \& Steglich, C. E. G. (2010). Introduction to stochastic actor-based models for network dynamics. Social Networks, 32(1), 44-60. https://doi.org/10.1016/j.socnet.2009.02.004

Steglich, C., Snijders, T. A. B., \& Pearson, M. (2010). Dynamic networks and behavior: Separating selection from influence. Sociological Methodology, 40(1), 329-393. https://doi.org/10.1111/j.1467-9531.2010.01225.x

Torrente, C. E., Cappella, E., \& Neal, J. W. (2014). Children's positive school behaviors and social preference in urban elementary classrooms. Journal of Community Psychology, 42(2), 143-161. https://doi.org/10.1002/jcop.21599 
Traag, T., Lubbers, M., \& van der Velden, R. K. W. (2012). That's what friends are for? The impact of peer characteristics on early schoolleaving. METEOR, Maastricht University School of Business and Economics. METEOR Research Memorandum No. 023. https://doi.org/10.26481/umamet.2012023

Twenge, J. M., Baumeister, R. F., DeWall, C. N., Ciarocco, N. J., \& Bartels, J. M. (2007). Social exclusion decreases prosocial behavior. Journal of Personality and Social Psychology, 92(1), 56-66. https://doi.org/10.1037/0022-3514.92.1.56

Vaillancourt, T., \& Hymel, S. (2006). Aggression and social status: The moderating roles of sex and peer-valued characteristics. Aggressive Behavior, 32(4), 396-408. https://doi.org/10.1002/ab.20138

Veenstra, R., Dijkstra, J. K., Steglich, C., \& Van Zalk, M. H. W. (2013). Network-behavior dynamics. Journal of Research on Adolescence, 23(3), 399-412. https://doi.org/10.1111/jora.12070

Wentzel, K. R. (1999). Social-motivational processes and interpersonal relationships: Implications for understanding motivation at school. Journal of Educational Psychology, 91(1), 76-97. https://doi.org/10.1037/0022-0663.91.1.76

Wentzel, K. (2015). Prosocial behaviour and schooling. In Encyclopedia of early childhood development. Retrieved June 10, 2019 from https://www.child-encyclopedia.com/pdf/expert/prosocial-behaviour/according-experts/prosocial-behaviour-and-schooling

Wentzel, K. R., \& Caldwell, K. (1997). Friendships, peer acceptance, and group membership: Relations to academic achievement in middle school. Child Development, 68(6), 1198-1209. https://doi.org/10.1111/j.1467-8624.1997.tb01994.x

Winston, G. C., \& Zimmerman, D. J. (2004). Peer effects in higher education. In C. M. Hoxby (Ed.), College choices: The economics of where to go, when to go, and how to pay for it. University of Chicago Press.

Xie, H., Cairns, R. B., \& Cairns, B. D. (1999). Social networks and configurations in inner-city schools: Aggression, popularity, and implications for students with EBD. Journal of Emotional and Behavioral Disorders, 7(3), 147-155. https://doi.org/10.1177/106342669900700303

Fecha de recepción: Agosto de 2019.

Fecha de aceptación: Abril de 2021. 